\title{
Thiazolidinedione drugs down-regulate CXCR4 expression on human colorectal cancer cells in a peroxisome proliferator activated receptor $\gamma$-dependent manner
}

\author{
CYNTHIA LEE RICHARD and JONATHAN BLAY \\ Department of Pharmacology, Faculty of Medicine, Dalhousie University, Halifax, Nova Scotia, B3H 1X5, Canada
}

Received October 26, 2006; Accepted December 4, 2006

\begin{abstract}
Peroxisome proliferator activated receptor (PPAR) $\gamma$ is a nuclear receptor involved primarily in lipid and glucose metabolism. PPAR $\gamma$ is also expressed in several cancer types, and has been suggested to play a role in tumor progression. PPAR $\gamma$ agonists have been shown to reduce the growth of colorectal carcinoma cells in culture and in xenograft models. Furthermore, the PPAR $\gamma$ agonist thiazolidinedione has been shown to reduce metastasis in a murine model of rectal cancer. Since the chemokine receptor CXCR4 has emerged as an important player in tumorigenesis, particularly in the process of metastasis, we sought to determine if PPAR $\gamma$ agonists might act in part by reducing CXCR4 expression. We found that rosiglitazone, a thiazolidinedione PPAR $\gamma$ agonist used primarily in the treatment of type 2 diabetes, significantly reduced cell-surface expression of CXCR4 protein on HT-29 human colorectal carcinoma cells. This effect occurred at concentrations as low as $1 \mathrm{nM}$, and was first evident after $8 \mathrm{~h}$ of drug exposure. CXCR4 mRNA was also down-regulated after treatment with rosiglitazone, indicating that the effect occurs at the level of transcription. Four other thiazolidinedione compounds (ciglitazone, pioglitazone, troglitazone, and MCC555) also significantly reduced CXCR4 expression. To confirm the involvement of PPAR $\gamma$ in thiazolidinedioneinduced CXCR4 down-regulation, we used PPAR $\gamma$ antagonists GW9662 and T0070907, both of which completely blocked the effect of rosiglitazone on CXCR4 expression. Furthermore, HT-29 cells in which PPAR $\gamma$ expression was reduced using shRNA were less responsive to rosiglitazone. In conclusion, we have shown that thiazolidinedione compounds reduce CXCR4 mRNA and cell-surface protein expression in a PPAR $\gamma$-dependent manner.
\end{abstract}

Correspondence to: Dr Jonathan Blay, Department of Pharmacology, Faculty of Medicine, Sir Charles Tupper Building, Dalhousie University, Halifax, Nova Scotia, B3H 1X5, Canada

E-mail: jonathan.blay@dal.ca

Key words: CXCR4, peroxisome proliferator activated receptor $\gamma$, colorectal cancer, thiazolidinedione

\section{Introduction}

Peroxisome proliferator activated receptors (PPARs) are nuclear hormone receptors that are involved primarily in lipid and glucose metabolism (1). Upon ligand activation, these receptors interact with the retinoid $\mathrm{X}$ receptor (RXR) and bind to peroxisome proliferator response elements (PPREs), leading to transcriptional regulation of target genes. Members of the thiazolidinedione class of antidiabetic drugs act as ligands for PPAR $\gamma$ (2), as does endogenously produced 15deoxy- $\Delta^{12,14}$-prostaglandin $\mathrm{J}_{2}\left(15 \mathrm{dPGJ}_{2}\right)$ (3).

In addition to regulation of glucose metabolism, PPAR $\gamma$ appears also to be involved in tumorigenesis, although its exact role has yet to be elucidated (4). PPAR $\gamma$ is expressed in a number of tumor types, including colorectal cancer $(5,6)$, and PPAR $\gamma$ agonists have been shown to inhibit the growth of cancer cells grown both in culture and in xenograft models (5,7-9). Interestingly, in a murine model of rectal cancer, a thiazolidinedione PPAR $\gamma$ agonist was shown also to inhibit the metastasis of colorectal carcinoma cells to lung and lymph nodes (9).

Chemokines and their receptors have emerged as important players in metastasis. One chemokine receptor in particular, CXCR4, can influence the metastatic process in a number of cancer types by altering both the dissemination of cancer cells $(10,11)$ and their growth at the site to which they have emigrated $(12,13)$. In the case of colorectal cancer, reduced CXCR4 expression leads to decreased growth of metastases in an animal model (13), whereas in human studies high CXCR4 expression has been associated with disease progression and with poorer prognosis and increased mortality $(14,15)$. Regulation of CXCR4 expression therefore is one strategy that might be effective as a means of interfering with the metastatic process. This rationale is supported by findings that direct inhibition of CXCR4 function reduces tumor growth in experimental models $(16,17)$.

Since thiazolidinedione drugs have been shown to reduce the metastasis of colorectal cancer cells in a pre-clinical model (9), and metastasis in colorectal cancer depends greatly on CXCR4 levels, we sought to determine if such PPAR $\gamma$ agonists might exert their effects in part by reducing the expression of CXCR4 on colorectal carcinoma cells. Thiazolidinedione drugs have been shown to inhibit cytokine-induced production of the chemokines MCP-1 and eotaxin (18) and expression of 
the chemokine receptor CCR2 (19), but to our knowledge this is the first study to examine regulation of CXCR4 on cancer cells by PPAR $\gamma$. We show here that thiazolidinedione compounds significantly reduce CXCR 4 mRNA and protein expression, and that this down-regulation is mediated through the activation of PPAR $\gamma$.

\section{Materials and methods}

Materials. We used the HT-29 human colorectal carcinoma cell line for this study, as it expresses high levels of CXCR4 (20). HT-29 cells were obtained from the American Type Culture Collection (Manassas, VA). Ciglitazone, pioglitazone, rosiglitazone, troglitazone, MCC555, GW9662, and T0070907 were purchased as a PPAR $\gamma$ PAK from Cayman Chemical (Ann Arbor, MI). Mouse monoclonal antibody against human CXCR4 (clone 12G5) and mouse $\mathrm{IgG}_{2 \mathrm{a}}$ (clone G155-178) were from BD Pharmingen (San Diego, CA), mouse monoclonal antibody against human PPAR $\gamma$ was a kind gift from Dr Mark Nachtigal (Dalhousie University), and secondary ${ }^{125}$ I-labeled goat anti-mouse IgG was obtained from Perkin-Elmer Life Sciences (NEN, Boston, MA). Brilliant SYBR ${ }^{\circledR}$-Green kits were from Stratagene (Cedar Creek, TX). Media, sera, culture vessels (Nunc), Lipofectamine ${ }^{\mathrm{TM}}$ 2000, T4 ligase, G418, and all other supplies for real-time RT-PCR were from Invitrogen Canada (Burlington, Ontario, Canada). QiaFilter Plasmid Maxi kits were from Qiagen (Mississauga, Ontario, Canada). Restriction enzymes were from Fermentas (Burlington, Ontario, Canada).

Cell culture. HT-29 cells were cultured in DMEM containing $5 \% \mathrm{v} / \mathrm{v}$ newborn calf serum (NCS), and were routinely passaged at sub-confluent densities. HT-29.luckd and HT29.shPPAR $\gamma$ cells were cultured in DMEM containing $10 \%$ NCS. For radioantibody binding assays, cells were subcultured into 48-well plates in DMEM containing 10\% NCS at a density of 50,000 cells/well. After allowing the cells to attach for $48 \mathrm{~h}$, the medium was replaced with DMEM containing $1 \% \mathrm{NCS}$, and drug treatments were performed after a further $48 \mathrm{~h}$. For real-time RT-PCR, 6-well plates were seeded at 200,000 cells/well in DMEM 10\% NCS, with a medium change after $48 \mathrm{~h}$ to DMEM $1 \%$ NCS and followed by drug treatments $48 \mathrm{~h}$ later. In all experiments, the final amount of vehicle (DMSO) was the same in all wells and did not exceed $0.1 \% \mathrm{v} / \mathrm{v}$.

Radioantibody binding assay for cell-surface CXCR4. Cells were cultured and treated as described in the previous paragraph, and radioantibody binding assays measuring cellsurface CXCR 4 were performed after $48 \mathrm{~h}$, unless otherwise indicated. The procedure was as described previously (20). Briefly, plates were placed on ice, and the cultures were washed with PBS containing $0.2 \%$ bovine serum albumin (BSA) followed by a 60-min incubation with $125 \mu 1$ PBS containing $1 \% \mathrm{BSA}$ and $1 \mu \mathrm{g} / \mathrm{ml}$ anti-CXCR4 or isotype control antibody. After two washes, the cells were incubated for 60 min with $125 \mu \mathrm{l}$ PBS containing $1 \% \mathrm{BSA}$ and $1 \mu \mathrm{Ci} / \mathrm{ml}$ ${ }^{125} \mathrm{I}$-labeled goat anti-mouse $\mathrm{IgG}$. Three more washes were performed, and the cells were then solubilized in $0.5 \mathrm{M} \mathrm{NaOH}$ and radioactivity was counted. To determine CXCR4-specific radioactivity, the cpm resulting from the isotype control were subtracted from those obtained with the CXCR4-specific antibody. Cell counts were performed with a Coulter ${ }^{\circledR}$ model ZM30383 particle counter (Beckman Coulter, Mississauga, Ontario, Canada), and the results shown are CXCR4-specific radioactivity $(\mathrm{cpm})$ per 1000 cells.

Real-time RT-PCR. Total RNA was isolated using TRIzol ${ }^{\circledR}$ according to the manufacturer's protocol, and 2-4 $\mu \mathrm{g}$ were reverse-transcribed using M-MLV reverse transcriptase and oligo $(\mathrm{dT})_{12-18}$ primer. Brilliant SYBR-Green was combined with cDNA and primers specific for CXCR4 (forward: 5'-GCC TGAGTGCTCCAGTAGCC-3'; reverse: 5'-GGAGTCATAG TCCCCTGAGC-3'), cytokeratin 20 (forward: 5'-ATGGATT TCAGTCGCAGAAGC-3'; reverse: 5'-CTCCCATAGTTCA CCGTGTGT-3'), PPAR $\gamma$ (forward: 5'-CGTGGATCTCTCC GTAATGG-3'; reverse: 5'-CCACTTTGATTGCACTTTGG-3') or GAPDH (forward: 5'-CATGAGAAGTATGACAACAG CCT-3'; reverse: 5'-AGTCCTTCCACGATACCAAAGT-3'), and real-time PCR amplification was performed using a Stratagene Mx3000P system (Cedar Creek). Relative mRNA expression was determined using the $2^{-\Delta \Delta \mathrm{cT}}$ method, with standardization against GAPDH and normalization to control treatment.

Knockdown of PPAR in HT-29 cells. The pSR-GFP/Neo plasmid (kindly provided by Dr Paola Marignani, Dalhousie University) was linearized using HindIII and $B g l$ III. The following oligonucleotides containing an shRNA sequence designed to reduce expression of PPAR $\gamma$ were annealed and inserted into the pSR-GFP/Neo plasmid using T4 ligase to generate the pSR.shPPAR $\gamma$ plasmid: 5'-GATCCCCGCCCT TCACTACTGTTGACTTCAAGAGAGTCAACAGTAG TGAAGGGCTTTTTA-3'; 5'-GCTTAAAAAGCCCTTCA CTACTGTTGACTCTCTTGAAGTCAACAGTAGTG AAGGGCGGG-3'. The sequence was chosen based on a siRNA sequence described by Schaefer and colleagues (21). E. coli $(\mathrm{DH} 5 \alpha)$ were transformed with $\mathrm{pSR} . \operatorname{shPPAR} \gamma$ and plasmid DNA was purified using a QiaFilter Plasmid Maxi kit. A control plasmid containing an shRNA sequence designed to reduce expression of luciferase (pSR.luckd) was kindly provided by Dr Mark Nachtigal (Dalhousie University). HT-29 cells were transfected with pSR.luckd or pSR.shPPAR $\gamma$ using Lipofectamine 2000 as per manufacturer's specifications, and stable transfectants were selected using G418 (800 $\mu \mathrm{g} / \mathrm{ml})$. Individual clones were expanded and screened for PPAR $\gamma$ mRNA expression using real-time RT-PCR. Stable cell lines chosen for study are referred to as HT-29.luckd or HT29.shPPAR $\gamma$.

Western blotting for PPAR protein. Total cellular protein was isolated from HT-29.luckd or HT-29.shPPAR $\gamma$ cells grown to $\sim 80 \%$ confluence in $10-\mathrm{cm}$ plates. Cells were rinsed twice with ice-cold PBS and dissolved in lysis buffer [50 mM HEPES (pH 7.4), $150 \mathrm{mM} \mathrm{NaCl}, 10 \%$ glycerol, $1.5 \mathrm{mM} \mathrm{MgCl}_{2}$, 1 mM EGTA, $1 \%$ Triton X-100, $1 \%$ sodium deoxycholate, $0.1 \%$ SDS, $1 \mathrm{mM}$ PMSF, $1 \mathrm{X}$ protease inhibitor mix] for $20 \mathrm{~min}$ at $4^{\circ} \mathrm{C}$. The cell lysates were clarified by centrifugation $(10 \mathrm{~min}$ at $12,000 \mathrm{x} \mathrm{g}$ and $4^{\circ} \mathrm{C}$ ) and quantified by Bradford protein assay according to the manufacturer's instructions. Twenty 
A

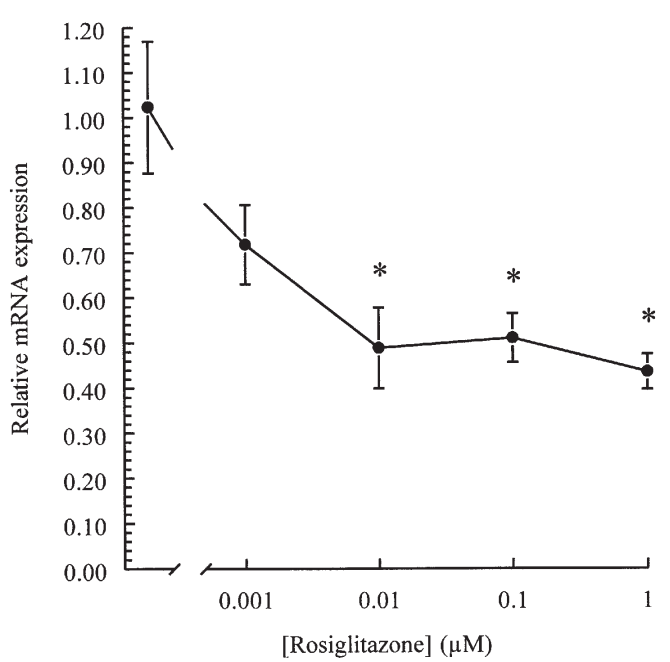

B

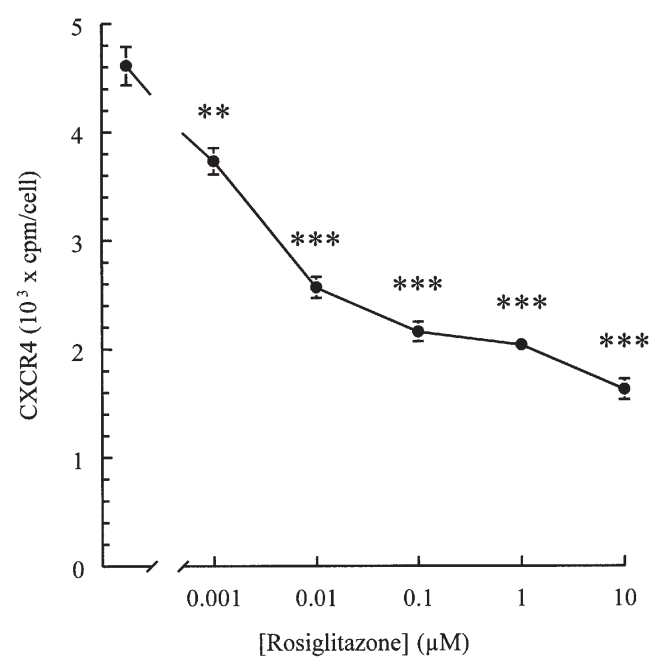

Figure 1. Rosiglitazone causes down-regulation of CXCR4 mRNA, and of CXCR4 receptor protein at the surface of HT-29 cells. A, HT-29 cells were treated with rosiglitazone at the concentrations indicated, and mRNA expression was measured after $24 \mathrm{~h}$ using real-time PCR. B, cell-surface CXCR4 protein expression was measured after a 48 -h incubation with rosiglitazone at the concentrations indicated. The data are mean values $\pm \mathrm{SE}$ (A, n=3; B, n=4) of representative experiments. Significant decrease due to rosiglitazone, ${ }^{* * *} \mathrm{P}<0.001 ;{ }^{* *} \mathrm{P}<0.01 ;{ }^{*} \mathrm{P}<0.05$.

micrograms of protein extract per lane were separated by SDS-PAGE using 10\% gels and electroblotted to nitrocellulose. Blots were blocked with $5 \%$ skim milk in Tris-buffered saline with $0.1 \%$ Tween-20 for $1 \mathrm{~h}$ at room temperature. Blots were then probed overnight at $4^{\circ} \mathrm{C}$ with anti-PPAR $\gamma$ antibody $(8 \mu \mathrm{g} / \mathrm{ml})$ followed by incubation with HRP-conjugated sheep anti-mouse IgG secondary antibody for $1 \mathrm{~h}$ at room temperature. Protein expression was detected using an enhanced chemiluminescence detection system. To confirm equal sample loading, the blots were stripped and re-probed for $\alpha$-actin.

\section{Results}

Rosiglitazone causes a dose- and time-dependent downregulation of CXCR4 $\mathrm{mRNA}$ and cell surface protein in colorectal carcinoma cells. We assessed the effects of thiazolidinediones on CXCR4 expression at both the mRNA and protein

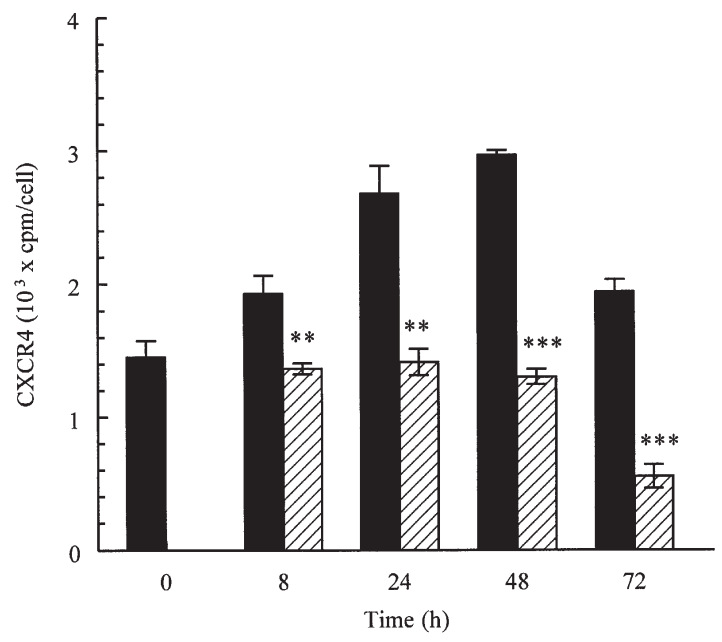

Figure 2. Time course of rosiglitazone effect on CXCR4 receptor expression. HT-29 cells were incubated with $10 \mathrm{nM}$ rosiglitazone (hatched bars) or control vehicle (solid bars) for the times indicated, and cell-surface CXCR4 protein expression was then measured. The data are mean values $\pm S E(n=4)$ of representative experiments. Significant decrease due to rosiglitazone, ${ }^{* * * *} \mathrm{P}<0.001 ;{ }^{* *} \mathrm{P}<0.01$.

levels. To measure changes at the level of mRNA, we performed quantitative RT-PCR with primers specific for CXCR4. After a 24-h treatment, $1 \mu \mathrm{M}$ rosiglitazone induced a greater than $57 \%$ reduction in CXCR4 mRNA expression in HT-29 cells, as shown in Fig. $1 \mathrm{~A}$. The $\mathrm{EC}_{50}$ for this effect of rosiglitazone was $\sim 1 \mathrm{nM}$, and the decrease in CXCR4 mRNA was near maximal by $\sim 10 \mathrm{nM}$ rosiglitazone (Fig. 1A). To assess changes in CXCR4 protein expression, we used a radioantibody binding assay that specifically detects cellsurface protein expression (22). This provides a good measure of the functional CXCR4 protein that is involved in mediating migratory and proliferative responses to CXCL12 (20). Rosiglitazone at a concentration of $1 \mu \mathrm{M}$ caused a $56 \%$ decrease in cell-surface CXCR4 expression (Fig. 1B), very close in magnitude to the decline in mRNA expression. The dosedependency of the effect on cell-surface receptor also closely paralleled the effect of rosiglitazone on mRNA level, with a statistically significant reduction being noted at a dose of $1 \mathrm{nM}$ (Fig. 1B).

We examined the time course of the suppression of CXCR4 protein at the HT-29 cell surface. Over a period of $\sim 3$ days, the level of CXCR4 on untreated HT-29 cells followed a cyclic course (Fig. 2; see also Fig. 1A in ref. 20). During this time-frame, which is $48 \mathrm{~h}$ after a change to fresh medium, the pool of cell-surface CXCR4 receptor first increases over the initial 24-48 $\mathrm{h}$ and then subsequently declines. This phasic change in CXCR4 levels is due to the consequence of cell turnover in fresh medium and the cell cycle phase-dependent nature of CXCR4 expression $(20,23)$. In accordance with this, rosiglitazone progressively suppressed the quantity of receptor per cell, by $29.4,47.3,56.2$ and $71.7 \%$ respectively at 8,24 , 48 and $72 \mathrm{~h}$ of treatment for the experiment shown in Fig. 2. This has the effect of ablating the increase and precipitating a faster and more marked decline.

CXCR4 down-regulation is a common response to all thiazolidinediones. We tested whether the ability to down-regulate 
A

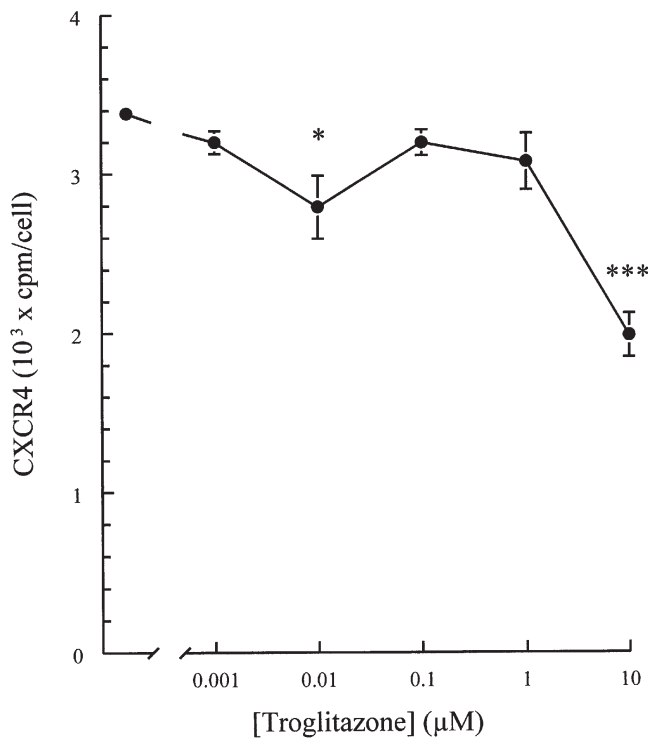

C

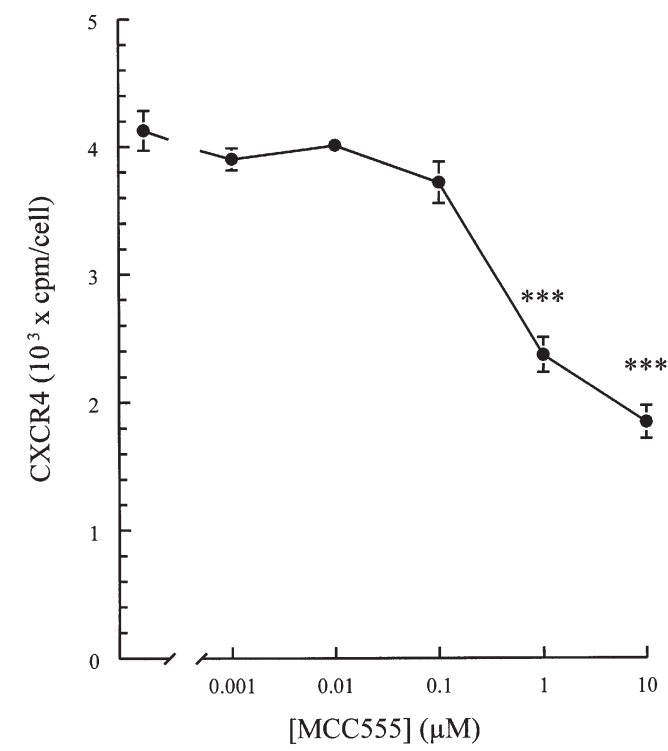

B

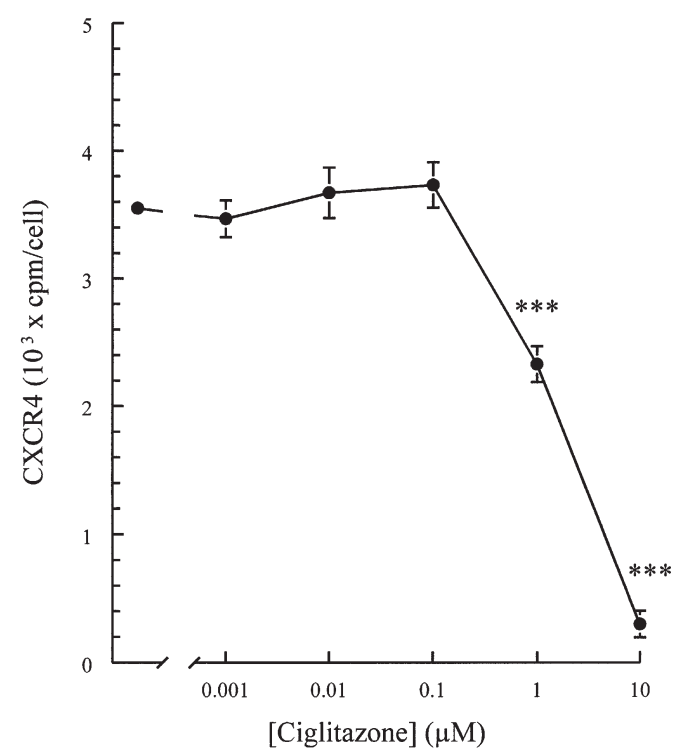

D

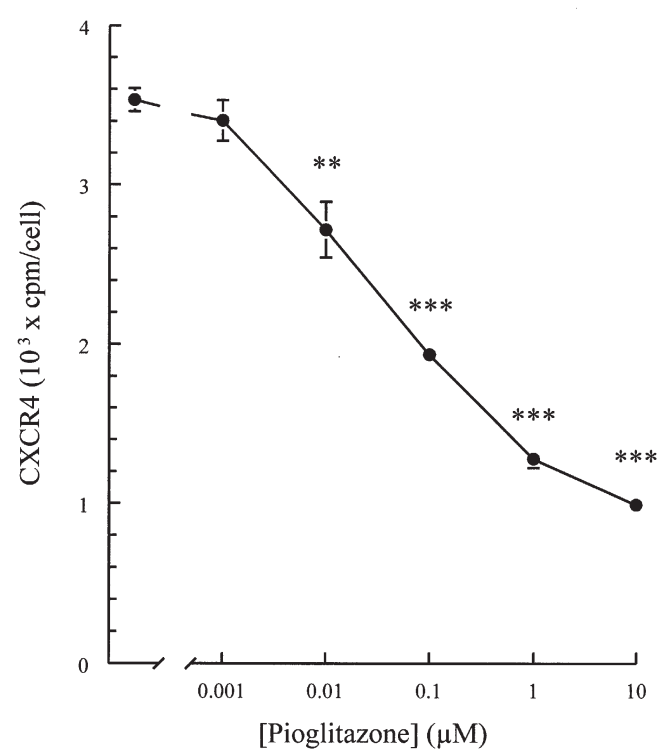

Figure 3. Dose-dependent down-regulation of CXCR4 is common to a range of thiazolidinediones. Cell-surface CXCR4 protein expression was measured after a 48-h incubation of HT-29 cells with (A) troglitazone, (B) ciglitazone, (C) MCC555, or (D) pioglitazone at the concentrations indicated. The data are mean values $\pm \mathrm{SE}(\mathrm{n}=4)$ from representative experiments. Significant decrease due to thiazolidinedione, ${ }^{* * *} \mathrm{P}<0.001 ;{ }^{* *} \mathrm{P}<0.01,{ }^{*} \mathrm{P}<0.05$.

CXCR4 was a property that was unique to rosiglitazone or was common to other thiazolidinediones. As shown in Fig. 3, all of the thiazolidinediones that we examined caused a decline in CXCR4 receptor protein, ranging from 41 to $92 \%$ at the highest dose $(10 \mu \mathrm{M})$ tested, and with a lowest effective concentration for these additional agents ranging from $10 \mathrm{nM}$ (pioglitazone) to $10 \mu \mathrm{M}$ (troglitazone). The rank order of potency for the ability of thiazolidinediones to down-regulate CXCR4 was rosiglitazone $>$ pioglitazone $>$ ciglitazone $=$ MCC555 > troglitazone (Figs. 1B and 3). The reduction in cell-surface CXCR4 expression followed a similar time course for each thiazolidinedione, with the effect first being noted at $8 \mathrm{~h}$ and maintained for $72 \mathrm{~h}$ after a single treatment (data not shown).

TZD-induced CXCR4 down-regulation is due to action on $P P A R \gamma$. The major action of thiazolidinediones is through binding to PPAR $\gamma(2)$, and the above rank order of potency of thiazolidinediones is consistent with an action of thiazolidinediones on CXCR4 expression that is mediated through PPAR $\gamma$ $(24,25)$. We confirmed using real-time PCR that HT-29 cells expressed PPAR $\gamma$ (data not shown). To confirm further that rosiglitazone was capable of activating PPAR $\gamma$-dependent pathways in HT-29 cells, we quantitated the expression of the mRNA for cytokeratin 20, a PPAR $\gamma$-dependent gene that is expressed in colon epithelial cells (26). Fig. 4 shows the expression of cytokeratin 20 mRNA following exposure of HT-29 cells to rosiglitazone; cytokeratin 20 mRNA expression was increased 2.4 -fold by $8 \mathrm{~h}$ after adding rosiglitazone, confirming that rosiglitazone is able to induce PPAR $\gamma$ dependent responses in these cells.

We used two PPAR $\gamma$ antagonists to determine whether there was involvement of PPAR $\gamma$ in rosiglitazone-induced CXCR4 down-regulation in HT-29 cells. The PPAR $\gamma$ antagonists were added $30 \mathrm{~min}$ prior to rosiglitazone, and CXCR4 cellsurface expression was assessed $48 \mathrm{~h}$ after rosiglitazone 


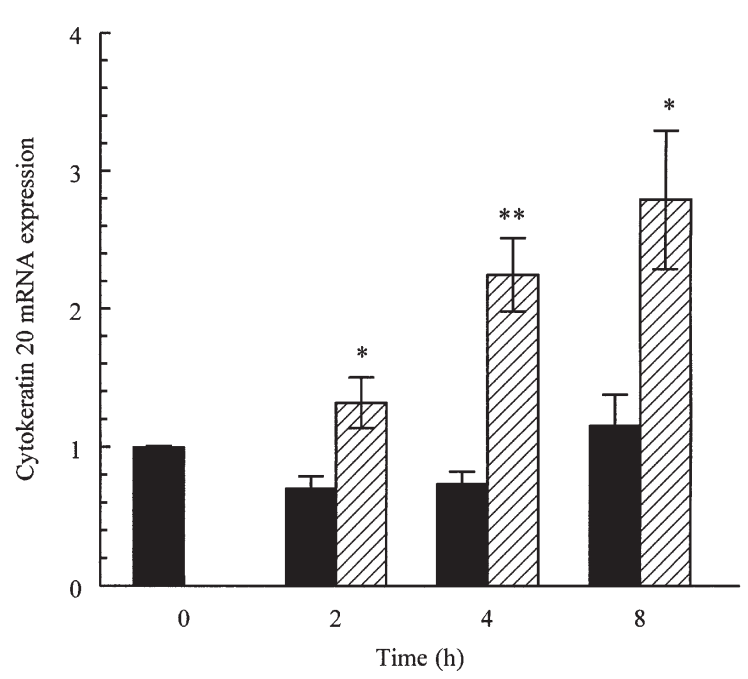

Figure 4. Rosiglitazone enhances mRNA expression of the PPAR $\gamma$-dependent gene for cytokeratin 20 in HT-29 cells. HT-29 cells were treated with vehicle (solid bars) or $1 \mu \mathrm{M}$ rosiglitazone (hatched bars), and RNA was isolated at the indicated time-points. Cytokeratin 20 mRNA expression was quantified using real-time RT-PCR. The data are mean values \pm SE $(n=3)$. Significant increase due to rosiglitazone, ${ }^{* *} \mathrm{P}<0.01 ;{ }^{*} \mathrm{P}<0.05$.

treatment as before. Two distinct PPAR $\gamma$ antagonists, GW9662 and T0070907, both completely blocked rosiglitazone-induced CXCR4 down-regulation (Table I). This shows that CXCR4 is down-regulated through a PPAR $\gamma$-dependent phenomenon. T0070907 itself substantially increased CXCR4 receptor expression (Table I). However, this appears not to be a PPAR $\gamma$ mediated effect since a corresponding shift was not seen with GW9662.

To confirm that rosiglitazone-induced CXCR4 downregulation occurred in a PPAR $\gamma$-dependent manner, we stably transfected HT-29 cells with an shRNA sequence designed to reduce PPAR $\gamma$ expression. Using this approach, PPAR $\gamma$ mRNA expression was reduced by $74 \%$ (Fig. 5A) and protein by $66 \%$ (Fig. 5B). As shown in Fig. 5C, the effect of rosiglitazone on CXCR4 expression was diminished in HT-29.PPAR $\gamma$ cells compared to control HT-29.luckd cells $(\mathrm{P}<0.05$, two-way ANOVA), further establishing PPAR $\gamma$ involvement in the rosiglitazone effect.

\section{Discussion}

We have shown here that thiazolidinedione PPAR $\gamma$ agonists reduce the expression of $\mathrm{CXCR} 4$, a chemokine receptor implicated in metastasis, on HT-29 colorectal carcinoma cells. This effect occurred at both the mRNA and cell-surface protein level, and was noted with all five thiazolidinedione compounds tested.

We have concentrated particularly in our studies on measuring changes in cell-surface CXCR4 receptor protein rather than total protein or CXCR4 message, as this is the ultimate pool of gene product that is responsible for cellular migration and proliferation in response to CXCL12 (20). Recent tandem genomic and proteomic analyses of cellular responses have shown poor concordance between mRNA transcript and protein expression changes, such that changes in mRNA and protein in response to stimuli may even be in opposite directions (27). For CXCR4 in cell populations, it is entirely possible to see an up-regulation of mRNA expression but a down-regulation of cell surface protein (28), or an increase in cell-surface receptor that occurs independently of changes in transcription (29). This raises significant questions about the interpretation of mRNA changes, and is the reason that we have focused upon cell-surface CXCR4 in these and other (20) studies. Nevertheless, the close correlation in these studies between the time courses, magnitudes and dosedependencies of the mRNA and protein responses suggest that thiazolidinedione-induced changes in CXCR4 expression occur mainly at the level of transcription, rather than through post-translational modifications or alterations in receptor trafficking to the cell surface.

The order of potency of thiazolidinediones in reducing CXCR4 expression (rosiglitazone $>$ pioglitazone $>$ ciglitazone $=$ MCC555 $>$ troglitazone) corresponds with their known potencies as PPAR $\gamma$ agonists $(2,24,25)$. Troglitazone and MCC555 both act as partial agonists at PPAR $\gamma$ receptors $(24,25)$ whereas the other thiazolidinediones are full agonists (25). Therefore, it is not surprising that these agents (troglitazone and MCC555) are the least effective in producing a down-regulation of CXCR4 expression.

There are however reports of thiazolidinedione-induced cellular effects that occur independently of PPAR $\gamma$ (30-32).

Table I. PPAR $\gamma$ antagonists block the down-regulation of CXCR4 due to rosiglitazone.

\begin{tabular}{|c|c|c|c|c|}
\hline \multirow{2}{*}{ Experiment } & \multirow{2}{*}{$\begin{array}{c}\text { PPAR } \gamma \\
\text { antagonist }\end{array}$} & \multicolumn{2}{|c|}{ Treatment } & \multirow{2}{*}{$\begin{array}{l}\text { Decrease due to } \\
\text { rosiglitazone }(\%)\end{array}$} \\
\hline & & Control & Rosiglitazone & \\
\hline \multirow[t]{2}{*}{$\mathrm{i}$} & Control & $2.53 \pm 0.14$ & $0.95 \pm 0.09^{a}$ & 63 \\
\hline & GW9662 & $2.47 \pm 0.22$ & $2.43 \pm 0.27 \mathrm{~ns}$ & 2 \\
\hline \multirow[t]{2}{*}{ ii. } & Control & $1.90 \pm 0.17$ & $0.81 \pm 0.11^{\mathrm{b}}$ & 57 \\
\hline & T0070907 & $2.74 \pm 0.17$ & $3.07 \pm 0.18 \mathrm{~ns}$ & 0 \\
\hline
\end{tabular}

HT-29 cells were treated with: i) GW9662 at $1 \mu \mathrm{M}$ or ii) T0070907 at $100 \mathrm{nM}$, or the corresponding vehicle controls, for 30 min before exposure to rosiglitazone $(10 \mathrm{nM})$ or vehicle control. Cell-surface CXCR4 protein expression was measured after $48 \mathrm{~h}$. The data are mean values $\pm \mathrm{SE}(\mathrm{n}=4)$. Significant change due to rosiglitazone, ${ }^{\mathrm{a}} \mathrm{P}<0.001$; ${ }^{\mathrm{b}} \mathrm{P}<0.01 ; \mathrm{ns}$, not significant. 
A

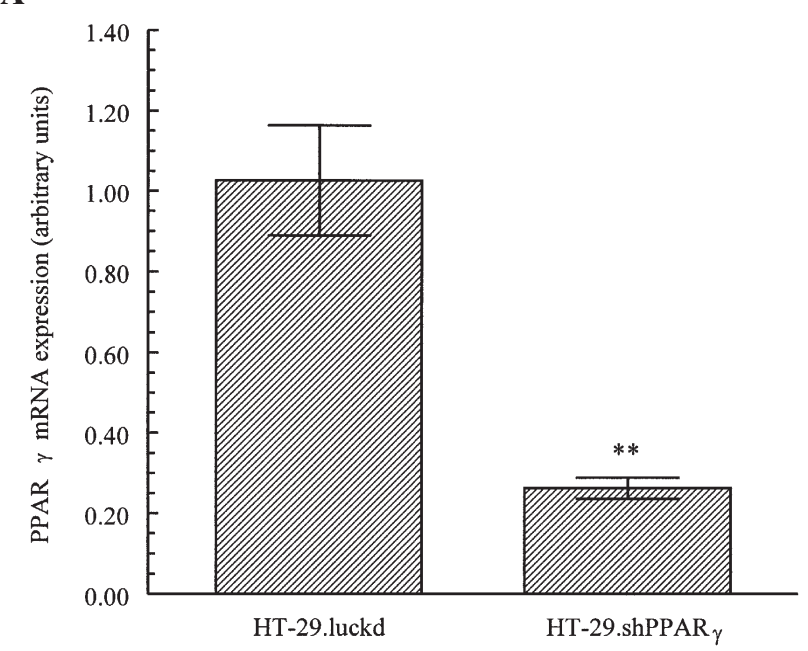

B

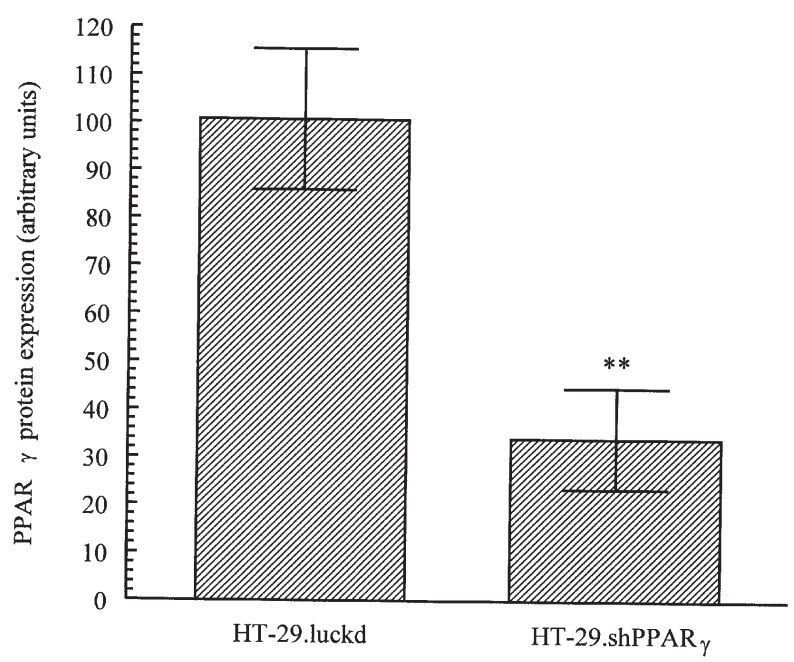

C

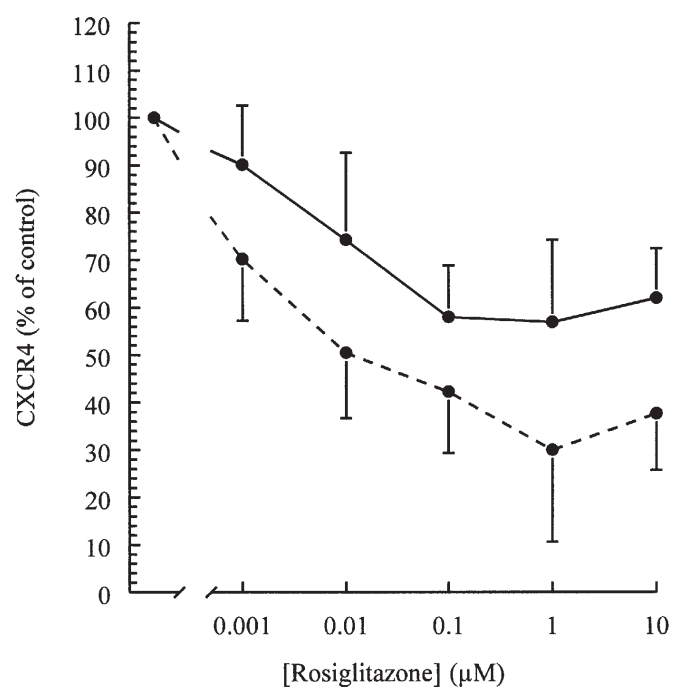

Figure 5. The effect of rosiglitazone is reduced in cells that express lower PPAR $\gamma$ levels. A, RNA was isolated from HT-29.luckd and HT-29.shPPAR $\gamma$ cells, and PPAR $\gamma$ mRNA expression was quantified using real-time RT-PCR. The data are mean values $\pm \mathrm{SE}(\mathrm{n}=4) .{ }^{* *}$ Significant reduction compared to HT-29.luckd cells, $\mathrm{P}<0.01$. B, total cell protein from HT-29.luckd and HT29.shPPAR $\gamma$ cells was analyzed for PPAR $\gamma$ by Western blotting. The data are mean values $\pm \mathrm{SE}(\mathrm{n}=4)$. ${ }^{* *}$ Significant reduction compared to HT-29.luckd cells, P<0.01. C, HT-29.luckd (broken line) and HT-29.shPPAR $\gamma$ (solid line) cells were treated with rosiglitazone at the indicated concentrations, and cell-surface CXCR 4 protein expression was measured after $48 \mathrm{~h}$. The data are normalized values pooled from 3-4 independent experiments \pm SE.
Therefore, although the potency correlation in our study was indicative of PPAR $\gamma$ involvement, we used PPAR $\gamma$-selective antagonists to confirm the involvement of PPAR $\gamma$. The PPAR $\gamma$ antagonists GW9662 and T0070907 both completely blocked the effects of rosiglitazone on CXCR4 expression. Rosiglitazone was able to induce cytokeratin 20 in these cells, confirming that the PPAR $\gamma$ pathway was active. Furthermore, HT-29 cells in which PPAR $\gamma$ expression was substantially reduced using shRNA were less responsive to rosiglitazone. Therefore, it appears that thiazolidinedione-induced CXCR4 down-regulation occurs in a PPAR $\gamma$-dependent manner. The exact mechanism of PPAR $\gamma$-mediated transcriptional repression of CXCR4 has yet to be determined. Although activation of PPAR $\gamma$ typically results in transactivation of target genes, transrepression has also been noted (4). For example, activated PPAR $\gamma$ can antagonize the effects of a number of transcription factors, including AP-1, STAT, and NF-кB, and thereby inhibit gene transcription (33). It is possible that the thiazolidinedione-induced CXCR4 down-regulation noted in our study is a result of PPAR $\gamma$-mediated NF- $\mathrm{BB}$ transrepression, since NF- $\mathrm{KB}$ activation induces CXCR4 transcription (34).

As CXCR4 expression is an important determinant of cancer metastasis $(10,13)$, agents that reduce CXCR4 expression on cancer cells could prove to be useful in the prevention of metastasis. The parent compound thiazolidinedione has been shown in pre-clinical studies to reduce the metastasis of HT-29 cells implanted in the rectums of mice (9). However, in a Phase II study of patients with advanced metastatic colorectal cancer that had not responded to chemotherapy, troglitazone failed to produce an objective tumor response (35). It is unclear whether or not this same lack of benefit would be noted with a more potent and selective PPAR $\gamma$ agonist such as rosiglitazone. Our data suggest that such an agent would produce a greater reduction in CXCR4 expression and would therefore be anticipated to have greater potential for an impact on metastasis.

The most likely potential use for thiazolidinediones is in combination with existing therapeutic approaches. The use of thiazolidinedione drugs in combination with chemotherapy is supported by a Phase II study in which all of six patients receiving metronomic chemotherapy together with pioglitazone as well as a COX-2 inhibitor for the treatment of angiosarcoma experienced clinical benefit (36). It is also consistent with pre-clinical studies in which a PPAR $\gamma$ agonist, RS5444, enhanced the activity of the cytotoxic drug paclitaxel against anaplastic thyroid carcinoma (37). Interestingly, in other pre-clinical studies, rosiglitazone was found to have myeloprotective effects when given in combination with or following 5-fluorouracil treatment $(38,39)$, while pioglitazone and netoglitazone have been shown to be protective of normal colonic mucosa in a model of colonic injury (40). Thiazolidinediones may therefore have potential benefit in the context of chemotherapeutic combinations both in enhancing the activity of cytotoxic therapeutics and in protecting sensitive normal tissues.

In conclusion, we have found that the thiazolidinedione class of PPAR $\gamma$ agonists down-regulates CXCR4 mRNA and cell-surface protein expression on HT-29 colorectal carcinoma cells in a PPAR $\gamma$-dependent manner. Further studies are warranted to elucidate the importance of this phenomenon in 
the pre-clinical and clinical settings in the context of cancer metastasis.

\section{Acknowledgements}

We are sincerely grateful to Drs Trevor Shepherd and Michelle Mujoomdar for invaluable assistance with the production of HT-29.luckd and HT-29.shPPAR $\gamma$ cell lines, and to Dr Mark Nachtigal for the kind gift of anti-PPAR $\gamma$. This study was supported by grants to J.B. from the Natural Sciences and Engineering Research Council of Canada (NSERC) and the Canadian Breast Cancer Foundation, and by studentship awards to C.L.R. from NSERC, the Killam Foundation and Cancer Care Nova Scotia.

\section{References}

1. Kota BP, Huang TH and Roufogalis BD: An overview on biological mechanisms of PPARs. Pharmacol Res 51: 85-94, 2005 .

2. Lehmann JM, Moore LB, Smith-Oliver TA, Wilkison WO, Willson TM and Kliewer SA: An antidiabetic thiazolidinedione is a high affinity ligand for peroxisome proliferatoractivated receptor $\gamma(\operatorname{PPAR} \gamma)$. J Biol Chem 270: 12953-12956, 1995.

3. Forman BM, Tontonoz P, Chen J, Brun RP, Spiegelman BM and Evans RM: 15-Deoxy- $\Delta^{12,14}$-prostaglandin $\mathbf{J}_{2}$ is a ligand for the adipocyte determination factor PPAR $\gamma$. Cell 83: 803-812, 1995.

4. Grommes C, Landreth GE and Heneka MT: Antineoplastic effects of peroxisome proliferator-activated receptor $\gamma$ agonists. Lancet Oncol 5: 419-429, 2004.

5. Sarraf P, Mueller E, Jones D, et al: Differentiation and reversal of malignant changes in colon cancer through PPAR $\gamma$. Nat Med 4: 1046-1052, 1998.

6. Matthiessen MW, Pedersen G, Albrektsen T, Adamsen S, Fleckner J and Brynskov J: Peroxisome proliferator-activated receptor expression and activation in normal human colonic epithelial cells and tubular adenomas. Scand J Gastroenterol 40: 198-205, 2005.

7. Brockman JA, Gupta RA and Du Bois RN: Activation of PPAR $\gamma$ leads to inhibition of anchorage-independent growth of human colorectal cancer cells. Gastroenterology 115: 1049-1055, 1998.

8. Yang WL and Frucht H: Activation of the PPAR pathway induces apoptosis and COX-2 inhibition in HT-29 human colon cancer cells. Carcinogenesis 22: 1379-1383, 2001

9. Yoshizumi T, Ohta T, Ninomiya I, et al: Thiazolidinedione, a peroxisome proliferator-activated receptor- $\gamma$ ligand, inhibits growth and metastasis of HT-29 human colon cancer cells through differentiation-promoting effects. Int J Oncol 25: 631-639, 2004.

10. Müller A, Homey B, Soto $\mathrm{H}$, et al: Involvement of chemokine receptors in breast cancer metastasis. Nature 410: 50-56, 2001.

11. Schimanski CC, Schwald S, Simiantonaki N, et al: Effect of chemokine receptors CXCR4 and CCR7 on the metastatic behavior of human colorectal cancer. Clin Cancer Res 11: $1743-1750,2005$

12. Scotton CJ, Wilson JL, Scott K, et al: Multiple actions of the chemokine CXCL12 on epithelial tumor cells in human ovarian cancer. Cancer Res 62: 5930-5938, 2002.

13. Zeelenberg IS, Ruuls-Van Stalle L and Roos E: The chemokine receptor CXCR4 is required for outgrowth of colon carcinoma micrometastases. Cancer Res 63: 3833-3839, 2003.

14. Kim J, Takeuchi H, Lam ST, et al: Chemokine receptor CXCR4 expression in colorectal cancer patients increases the risk for recurrence and for poor survival. J Clin Oncol 23: 2744-2753, 2005.

15. Ottaiano A, Franco R, Aiello Talamanca A, et al: Overexpression of both CXC chemokine receptor 4 and vascular endothelia growth factor proteins predicts early distant relapse in Stage IIIII colorectal cancer patients. Clin Cancer Res 12: 2795-2803, 2006.

16. Bertolini F, Dell'Agnola C, Mancuso P, et al: CXCR4 neutralization, a novel therapeutic approach for non-Hodgkin's lymphoma. Cancer Res 62: 3106-3112, 2002.
17. Tamamura H, Hori A, Kanzaki N, et al: T140 analogs as CXCR4 antagonists identified as anti-metastatic agents in the treatment of breast cancer. FEBS Lett 550: 79-83, 2003.

18. Nie M, Corbett L, Knox AJ and Pang L: Differential regulation of chemokine expression by peroxisome proliferator-activated receptor $\gamma$ agonists: interactions with glucocorticoids and $\beta_{2}$ agonists. J Biol Chem 280: 2550-2561, 2005.

19. Han KH and Quehenberger O: Ligands for peroxisome proliferator-activated receptor inhibit monocyte CCR2 expression stimulated by plasma lipoproteins. Trends Cardiovasc Med 10: 209-216, 2000.

20. Richard CL, Tan EY and Blay J: Adenosine up-regulates CXCR4 and enhances the proliferative and migratory responses of human carcinoma cells to CXCL12/SDF-1 $\alpha$. Int J Cancer 119: 2044-2053, 2006.

21. Schaefer KL, Wada K, Takahashi H, et al: Peroxisome proliferator-activated receptor $\gamma$ inhibition prevents adhesion to the extracellular matrix and induces anoikis in hepatocellular carcinoma cells. Cancer Res 65: 2251-2259, 2005.

22. Tan EY, Mujoomdar M and Blay J: Adenosine down-regulates the surface expression of dipeptidyl peptidase IV on HT-29 human colorectal carcinoma cells: implications for cancer cell behaviour. Am J Pathol 165: 319-330, 2004.

23. Shibuta K, Mori M, Shimoda K, Inoue H, Mitra P and Barnard GF Regional expression of CXCL12/CXCR4 in liver and hepatocellular carcinoma and cell-cycle variation during in vitro differentiation. Jpn J Cancer Res 93: 789-797, 2002.

24. Reginato MJ, Bailey ST, Krakow SL, Minami C, Ishii S, Tanaka $\mathrm{H}$ and Lazar MA: A potent antidiabetic thiazolidinedione with unique peroxisome proliferator-activated receptor $\gamma$-activating properties. J Biol Chem 273: 32679-32684, 1998

25. Camp HS, Li O, Wise SC, et al: Differential activation of peroxisome proliferator-activated receptor- $\gamma$ by troglitazone and rosiglitazone. Diabetes 49: 539-547, 2000.

26. Gupta RA, Brockman JA, Sarraf P, Willson TM and Du Bois RN: Target genes of peroxisome proliferator-activated receptor $\gamma$ in colorectal cancer cells. J Biol Chem 276: 29681-29687, 2001 .

27. Fessler MB, Malcolm KC, Duncan MW and Worthen GS: A genomic and proteomic analysis of activation of the human neutrophil by lipopolysaccharide and its mediation by 38 mitogen-activated protein kinase. J Biol Chem 277: 31291-31302, 2002.

28. Brühl H, Cohen CD, Linder S, Kretzler M, Schlöndorff D and Mack M: Post-translational and cell type-specific regulation of CXCR4 expression by cytokines. Eur J Immunol 33: 3028-3037, 2003.

29. Cole SW, Jamieson BD and Zack JA: cAMP up-regulates cell surface expression of lymphocyte CXCR4: implications for chemotaxis and HIV-1 infection. J Immunol 162: 1392-1400, 1999.

30. Palakurthi SS, Aktas H, Grubissich LM, Mortensen RM and Halperin JA: Anticancer effects of thiazolidinediones are independent of peroxisome proliferator-activated receptor $\gamma$ and mediated by inhibition of translation initiation. Cancer Res 61: 6213-6218, 2001

31. Akasaki Y, Liu G, Matundan $\mathrm{HH}$, et al: A peroxisome proliferatoractivated receptor- $\gamma$ agonist, troglitazone, facilitates caspase- 8 and -9 activities by increasing the enzymatic activity of proteintyrosine phosphatase-1B on human glioma cells. J Biol Chem 281: 6165-6174, 2006.

32. Han S and Roman J: Rosiglitazone suppresses human lung carcinoma cell growth through PPAR $\gamma$-dependent and PPAR $\gamma$ independent signal pathways. Mol Cancer Ther 5: 430-437, 2006.

33. Ricote M, Li AC, Willson TM, Kelly CJ and Glass CK: The peroxisome proliferator-activated receptor- $\gamma$ is a negative regulator of macrophage activation. Nature 391: 79-82, 1998.

34. Helbig G, Christopherson KW II, Bhat-Nakshatri P, et al: $\mathrm{NF}-\kappa \mathrm{B}$ promotes breast cancer cell migration and metastasis by inducing the expression of the chemokine receptor CXCR4. J Biol Chem 278: 21631-21638, 2003.

35. Kulke MH, Demetri GD, Sharpless NE, et al: A phase II study of troglitazone, an activator of the PPAR $\gamma$ receptor, in patients with chemotherapy-resistant metastatic colorectal cancer Cancer J 8: 395-399, 2002.

36. Vogt T, Hafner C, Bross K, et al: Antiangiogenetic therapy with pioglitazone, rofecoxib, and metronomic trofosfamide in patients with advanced malignant vascular tumors. Cancer 98: 2251-2256, 2003. 
37. Copland JA, Marlow LA, Kurakata S, et al: Novel high-affinity PPAR $\gamma$ agonist alone and in combination with paclitaxel inhibits human anaplastic thyroid carcinoma tumor growth via p21 $1_{\mathrm{WAF} 1 / \mathrm{CIP} 1}$. Oncogene 25: 2304-2317, 2006.

38. Djazayeri K, Szilvássy Z, Peitl B, et al: Accelerated recovery of 5-fluorouracil-damaged bone marrow after rosiglitazone treatment. Eur J Pharmacol 522: 122-129, 2005.
39. Djazayeri K, Szilvássy Z, Benkõ K, Rózsa B, Szabó B, Szentmiklósi AJ and Benkõ I: Effect of rosiglitazone, an insulin sensitizer, on myelotoxicity caused by repeated doses of 5fluorouracil. Pharmacol Res 53: 156-161, 2006.

40. Takaki K, Mitsuyama K, Tsuruta O, Toyonaga A and Sata M: Attenuation of experimental colonic injury by thiazolidinedione agents. Inflamm Res 55: 10-15, 2006. 